\title{
Article
}

\section{Anion Exchange Properties of Hydrous Metal Oxides. Analysis Based on Surface Complexation with Stability Constant Data Base}

\author{
*Kenta Ooi \\ National Institute of Advanced Industrial Science and Technology, \\ 2217-14, Hayashi-cho, Takamatsu 761-0395, Japan
}

(Manuscript submitted March 31, 2007; accepted May 11, 2007)

\begin{abstract}
Ion exchange properties of hydrous metal oxides (HMeOs) for weak base anions were discussed in terms of surface complexation using the metal-ligand stability constant data base at relatively high ionic strength. The selectivity sequences of anion were correlated comparatively well with the orders of first stepwise stability constants $\left(K_{1}\right)$ of the corresponding metal-ligand complexes. Conditions whether inner sphere or outer sphere surface complex forms could be evaluated by the difference in the stability constant between the $\mathrm{OH}^{-} / \mathrm{X}^{-}\left(\mathrm{X}^{-}\right.$: anion) and $\mathrm{OH}^{-} / \mathrm{H}_{2} \mathrm{O}$ ligand exchange reactions. These calculations suggest that the anion exchange reaction of $\mathrm{HMeO}$ is controlled mainly by the interactions of anions or $\mathrm{H}_{2} \mathrm{O}$ molecules with the central metal atoms.
\end{abstract}

Key words: anion exchange, selectivity, hydrous metal oxide, surface complexation model, stability constant

\section{Introduction}

Studies of anion exchange properties of $\mathrm{HMeOs}$ are important in the field not only of fundamental surface and separation chemistry but also of environmental- and geo-chemistry. From a standpoint of pollution control, there have been extensive studies on the adsorption of harmful anions (fluoride, arsenate, arsenite, selenate, selenite, phosphate, nitrate ions, etc.) on $\mathrm{HMeO}$ from lake, river, underground water, seawater, waste water, and drinking water. Several kinds of $\mathrm{HMeO}$, e.g. hydrous iron oxide, hydrous aluminum oxide, etc. with crystalline or amorphous structure are a promising material for the removal of harmful anions from aqueous solutions. The anion exchange reactions of $\mathrm{HMeOs}$ progress involving the hydroxyl groups formed on the surface of metal oxide crystallites; they show different acid-base properties depending on the kinds and properties of central metal atoms of $\mathrm{HMeO}$. Two kinds of anion exchange (adsorption) reactions are known with $\mathrm{HMeO}$ [1],

$$
\begin{array}{lll}
\mathrm{M}-\mathrm{OH}+\mathrm{X}^{-} & \overrightarrow{\mathrm{M}}-\mathrm{X}+\mathrm{OH}^{-} & \text {(ligand exchange) } \\
\mathrm{M}-\mathrm{OH}+\mathrm{X}^{-}+\mathrm{H}^{+} \rightleftarrows \mathrm{M}-\mathrm{OH}_{2}^{+}-\mathrm{X}^{-} & \text {(protonation) }
\end{array}
$$

where $\mathrm{M}$ is central metal atom of $\mathrm{HMeO}$. Selectivity sequence of anion exchange can be obtained by measurement of distribution coefficient $(K d)$ of anions on $\mathrm{HMeO}$ from a diluted solution. Selectivity sequences on different kinds of $\mathrm{HMeO}$ vary depending on the kind of central metal atoms, as is shown in the next section. 
It has been found that surface complexation model (SCM), which treats surface hydroxyl group as analogs of complexing ligand in solution, well describes the anion exchange behavior at the oxide/aqueous interface. The structure at the oxide/aqueous interface has been analyzed with several types of SCM: diffuse-layer model (DLM), constant capacitant model (CCM), triple-layer model (TLM), and extension of triple layer model (ETML) $[2,3]$. Anions at the solution/solid interface can be classified mainly into two groups in the DLM: strongly bound anions which form inner sphere (IS) surface complex with the central metal atoms of $\mathrm{HMeO}$ and weakly bound ones which form outer sphere (OS) surface complex. In the latter, $\mathrm{H}_{2} \mathrm{O}$ molecules are bound directly to the central metal atoms and anions in solutions interact outside the $\mathrm{H}_{2} \mathrm{O}$ molecules. Formations and structures of IS and OS surface complexes can be schematically written as Figure. 1. The ionic strength dependence of anion adsorption can be used as a criterion for the formation of IS or OS surface complex. Anion uptake is rarely influenced by ionic strength in the case of IS surface complex,

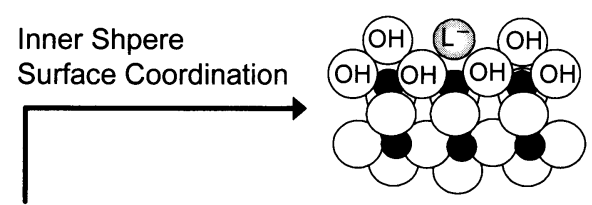

$\mathrm{OH}^{-} / \mathrm{L}$

Ligand exchange

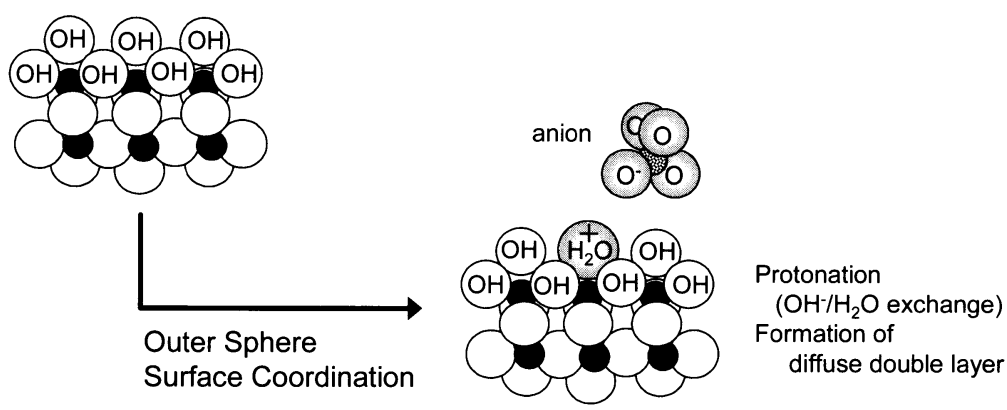

Figure. 1 Schematic representations of inner and outer sphere surface complexations

while it decreases markedly with ionic strength in the case of OS surface complex [4]. Using these models, several paratmeters (equilibrium constant of complex formation, acid-base constants, etc.) are derived from experimental results of anion exchange. These parameters are useful to simulate the exchange behaviors over the wide conditions of exchange reactions which cannot be determined experimentally.

This paper shows that stability constant (SC) data base [5] compiled by IUPAC is useful to predict the selectivity sequence of anion on $\mathrm{HMeO}$, especially consisting of trivalent and divalent metals. The correlation between the tendencies to form surface complex and to form the corresponding (inner-sphere) solute complex has been pointed out by W. Stumm for hydrous iron oxide and hydrous aluminum oxide, with $\mathrm{Fe}(\mathrm{OH})_{2}{ }^{+}$and $\mathrm{Al}(\mathrm{OH})_{2}{ }^{+}$ ions as solute, respectively [6]. However, to the best of my knowledge, there have been no reports that use SC data base in a general way to predict selectivity sequence of anions on various kinds of $\mathrm{HMeO}$. In addition to the prediction of selectivity sequence, SC data base is useful to distinguish whether IS or OS surface complex forms at a known condition. We studied only weak base anions in this paper, since the interaction between $\mathrm{HMeO}$ and weak base anions is simple because of no protonated species over a wide range of $\mathrm{pH}$.

\section{Selectivity sequences in the literatures}

Selectivity sequences of anions on inorganic ion exchangers, reported until now are summarized in Table 1. The selectivity sequence varies depending on its crystal structure and the kind of central metal atom. The selectivity orders can be classified roughly into two groups: that $\left(\mathrm{F}^{-}>\mathrm{Cl}^{-}>\mathrm{Br}^{-}>\mathrm{I}^{-}\right)$reverse to the Hofmeister series and the others. The former is observed for $\mathrm{HMeO}$ with central metal ions $\left(\mathrm{Al}^{3+}, \mathrm{Fe}^{3+}\right.$, tetravalent metals) belonging to hard acid. $\mathrm{HMeO}$ with central metal atoms $\left(\mathrm{Bi}^{3+}\right)$ belonging to rather soft acid (borderline acid) shows the different $(\mathrm{Br}->\mathrm{Cl}-)$ selectivity order., which follows the Hofmeister series $\left(\mathrm{I}^{-}>\mathrm{Br}^{-}>\mathrm{Cl}^{-}>\mathrm{F}^{-}\right)$. The 
strong base anion exchange resin with tetra-alkyl ammonium ions as a functional group (soft acid) also shows the selectivity order of Hofmeister series. These results suggest that the interaction between anion and the central metal of $\mathrm{HMeO}$ strongly affects the affinity of halide ion exchange properties and the concept of hard and soft acid and base (HSAB) [14] is useful to predict the selectivity order.

Table 1 Selectivity sequences of anion on hydrous metal oxides

\begin{tabular}{|c|c|c|}
\hline Inorganic ion exchanger & Selectivity sequence & Ref. \\
\hline $\mathrm{ZnO} \mathrm{nH}_{2} \mathrm{O}$ & $\mathrm{CrO}_{4}{ }^{2-}>\mathrm{C}_{2} \mathrm{O}_{4}{ }^{2-}>\mathrm{PO}_{4}{ }^{3-}>\mathrm{SO}_{3}{ }^{2-}>\mathrm{S}_{2} \mathrm{O}_{3}^{-}>\mathrm{I}^{-}>\mathrm{SO}_{4}{ }^{2-}>\mathrm{Cl}^{-}>\mathrm{NO}_{3}{ }^{-}$ & [7] \\
\hline $\mathrm{PbO} \mathrm{nH}_{2} \mathrm{O}$ & $\mathrm{CrO}_{4}{ }^{2-}>\mathrm{PO}_{4}{ }^{3-}>\mathrm{Cl}^{-}>\mathrm{S}_{2} \mathrm{O}_{3}^{-}>\mathrm{SO}_{3}{ }^{2-}>\mathrm{I}^{-}>\mathrm{SO}_{4}{ }^{2-}$ & [7] \\
\hline $\mathrm{Al}_{2} \mathrm{O}_{3} \mathrm{nH}_{2} \mathrm{O}$ & $\mathrm{F}^{-}>\mathrm{IO}_{4}^{-}>\mathrm{IO}_{3}^{-}>\mathrm{BrO}_{3}^{-}>\mathrm{Cl}^{-}>\mathrm{Br}^{-}>\mathrm{ClO}_{3}^{-}>\mathrm{I}^{-}$ & [4] \\
\hline $\begin{array}{l}\mathrm{Fe}_{2} \mathrm{O}_{3} \mathrm{nH}_{2} \mathrm{O} \\
\text { (heating at } 170^{\circ} \mathrm{C} \text { ) }\end{array}$ & $\begin{array}{l}\mathrm{OH}^{-}>\mathrm{AsO}_{4}^{3-}, \mathrm{B}_{4} \mathrm{O}_{7}^{2-}>\mathrm{PO}_{4}{ }^{3-}, \mathrm{F}^{-}>\mathrm{CO}_{3}{ }^{2-}>\mathrm{CrO}_{4}{ }^{2-}, \mathrm{SO}_{3}{ }^{2-}>\mathrm{SO}_{4}{ }^{2-}, \mathrm{IO}_{4}^{-}>\mathrm{S}_{2} \mathrm{O}_{3}^{-}> \\
\mathrm{BrO}_{3}^{-}>\mathrm{NO}_{2}^{-}, \mathrm{NO}_{3}^{-}>\mathrm{Cl}^{-}>\mathrm{ClO}_{3}^{-}>\mathrm{Br}^{-}>\mathrm{ClO}_{4}^{-}, \mathrm{I}^{-}\end{array}$ & [7] \\
\hline $\mathrm{FeOOH}$ & $\begin{array}{l}\mathrm{CO}_{3}{ }^{2-}, \mathrm{HPO}_{4}{ }^{2-}>\mathrm{SO}_{4}{ }^{2-}, \mathrm{NO}_{3}^{-}, \mathrm{Cl}^{-}(\alpha-\mathrm{FeOOH}, \mathrm{pH} 8) \\
\mathrm{HPO}_{4}{ }^{3-}>\mathrm{SO}_{4}{ }^{2-}>\mathrm{NO}_{3}{ }^{-}>\mathrm{CO}_{3}{ }^{2-}, \mathrm{Cl}^{-}(\beta-\mathrm{FeOOH}, \mathrm{pH} 8)\end{array}$ & [8] \\
\hline $\begin{array}{r}\mathrm{Fe}_{2} \mathrm{O}_{3} \mathrm{nH}_{2} \mathrm{O} \\
\text { (hematite) } \\
\end{array}$ & $\mathrm{Cr}_{2} \mathrm{O}_{7}^{2-}>\mathrm{MoO}_{4}^{2-}>\mathrm{VO}_{3}^{4-}$ & [7] \\
\hline $\mathrm{La}_{2} \mathrm{O}_{3} \mathrm{nH}_{2} \mathrm{O}$ & $\mathrm{PO}_{4}{ }^{3-}>\mathrm{C}_{2} \mathrm{O}_{4}{ }^{2-}>\mathrm{CrO}_{4}{ }^{2-}>\mathrm{MnO}_{4}{ }^{-}>\mathrm{I}^{-}>\mathrm{SO}_{4}{ }^{2-}>\mathrm{Cl}^{-}$ & [7] \\
\hline $\mathrm{Bi}_{2} \mathrm{O}_{3} \mathrm{nH}_{2} \mathrm{O}$ & $\begin{array}{l}\mathrm{CrO}_{4}^{2-}>\mathrm{C}_{2} \mathrm{O}_{4}{ }^{2-}>\mathrm{PO}_{4}{ }^{3-}>\mathrm{SO}_{4}{ }^{2-}>\mathrm{I}^{-} \\
\mathrm{PO}_{4}{ }^{3-}>\mathrm{SO}_{4}{ }^{2-}>\mathrm{Br}^{-}>\mathrm{Cl}^{-}>\mathrm{NO}_{3}^{-}\end{array}$ & $\begin{array}{l}{[7]} \\
{[9]}\end{array}$ \\
\hline $\mathrm{SnO}_{2} \mathrm{nH}_{2} \mathrm{O}$ & $\begin{array}{l}\mathrm{PO}_{4}{ }^{3-}>\mathrm{C}_{2} \mathrm{O}_{4}{ }^{2-}>\mathrm{SO}_{4}{ }^{2-}>\mathrm{Cr}_{2} \mathrm{O}_{7}{ }^{2-}>\mathrm{Cl}^{-}>\mathrm{MnO}_{4}^{-}>\mathrm{Br}^{-}>\mathrm{I}^{-} \\
\mathrm{SO}_{4}{ }^{2-}>\mathrm{Cl}^{-}>\mathrm{I}^{-}>\mathrm{Br}^{-}>\mathrm{NO}_{3}^{-}\end{array}$ & $\begin{array}{l}{[7]} \\
{[10]}\end{array}$ \\
\hline $\mathrm{TiO}_{2} \mathrm{nH}_{2} \mathrm{O}$ & $\begin{array}{l}\mathrm{As}(\mathrm{OH})_{4}^{-}>\mathrm{Te}_{2} \mathrm{O}_{3}^{-}>\mathrm{Se}_{2} \mathrm{O}_{3}^{-}>\mathrm{IO}_{3}^{-}>\mathrm{BrO}_{3}^{-}>\mathrm{ClO}_{3}^{-} \\
\mathrm{SO}_{4}^{2-}>\mathrm{Br}^{-}, \mathrm{Cl}^{-}>\mathrm{I}^{-}, \mathrm{NO}_{3}^{-}\end{array}$ & $\begin{array}{l}{[11]} \\
{[10]}\end{array}$ \\
\hline $\mathrm{SiO}_{2} \mathrm{nH}_{2} \mathrm{O}\left(\mathrm{Mg}^{2+}\right.$ loading $)$ & $\mathrm{PO}_{4}^{3-}>\mathrm{C}_{2} \mathrm{O}_{4}^{2-}>\mathrm{SO}_{4}^{2-}$ & [7] \\
\hline $\mathrm{CeO}_{2} \mathrm{nH}_{2} \mathrm{O}$ & $\begin{array}{l}\mathrm{F}^{-}>\mathrm{HPO}_{4}{ }^{2-}>\mathrm{SO}_{4}{ }^{2-}>\mathrm{Cl}^{-}, \mathrm{NO}_{3}^{-}(\mathrm{pH} 5) \\
\mathrm{As}(\mathrm{OH})_{4}^{-}>\mathrm{B}(\mathrm{OH})_{4}^{-}>\mathrm{HPO}_{4}{ }^{2-}>\mathrm{NO}_{3}^{-}, \mathrm{Cl}^{-}, \mathrm{F}^{-}(\mathrm{pH} 9)\end{array}$ & [12] \\
\hline $\mathrm{ZrO}_{2} \mathrm{nH}_{2} \mathrm{O}$ & $\mathrm{PO}_{4}^{3-}>\mathrm{F}^{-}>\mathrm{Cl}^{-}, \mathrm{SO}_{4}{ }^{2-}, \mathrm{NO}_{3}^{-}, \mathrm{Br}^{-}$ & {$[13]$} \\
\hline
\end{tabular}

Most of the HMeOs shows high selectivity for strong base oxo-anions (phosphate, arsenate, carbonate ions, etc). Since they have a tendency to bind cations (for example protons) easily, they can form IS surface complexes smoothly. For halate anions, several $\mathrm{HMeOs}$ show the selectivity order of $\mathrm{IO}_{3}{ }^{-}>\mathrm{BrO}_{3}{ }^{-}>\mathrm{ClO}_{3}{ }^{-}$ which agrees in the decreasing of order of ionic radius. The $\mathrm{pH}$ dependence of halate ion adsorption on $\gamma-\mathrm{Al}_{2} \mathrm{O}_{3}$ shows the formation of OS surface complex [3]. In the case of OS surface complex, it is reasonable to think that the affinity of anions are controlled mainly by the electrostatic interaction between anions and the positively charged $\mathrm{HMeO}$ surface, therefore it decreases with an increase in the radius of "hydrated" ions (with a decrease of ionic radius).

\section{Surface complexation based on solute complexation}

\subsection{Anion exchange selectivity}

The anion exchange reaction of $\mathrm{HMeO}$ can be written by eqs. 1 and 2 for IS and OS surface complexation reactions, respectively. The protonation reaction (eq. 2) has the same physical meaning as $\mathrm{H}_{2} \mathrm{O}$ coordination at the inner sphere of central metal. When the random mixing can be assumed for exchanged anions with a constant number of exchange site, the anion exchange reaction can be treated as a homogeneous solution reaction of complex formation. The complexation reaction of cations for various ligands are 
summarized as stability constant (S) data base by IUPAC [5]. The first stepwize stability constant $\left(K_{1}\right)$ can be written as follows,

$$
\mathrm{M}^{n+}{ }_{\text {aq. }}+\mathrm{X}^{-} \rightleftarrows \mathrm{MX}^{(n-1)^{+}} \quad K_{1}=[\mathrm{MX}] /([\mathrm{M}][\mathrm{X}])
$$

where metal ion $\mathrm{M}^{\mathrm{n}+}$ is in a hydrated form. Since metal ions are hydrated before the complexation reaction, the stability constant corresponds to the value of $\mathrm{H}_{2} \mathrm{O} / \mathrm{X}^{-}$ligand exchange.

The anion exchange reaction of $\mathrm{HMeO}$ can be written by two step reaction as follows,

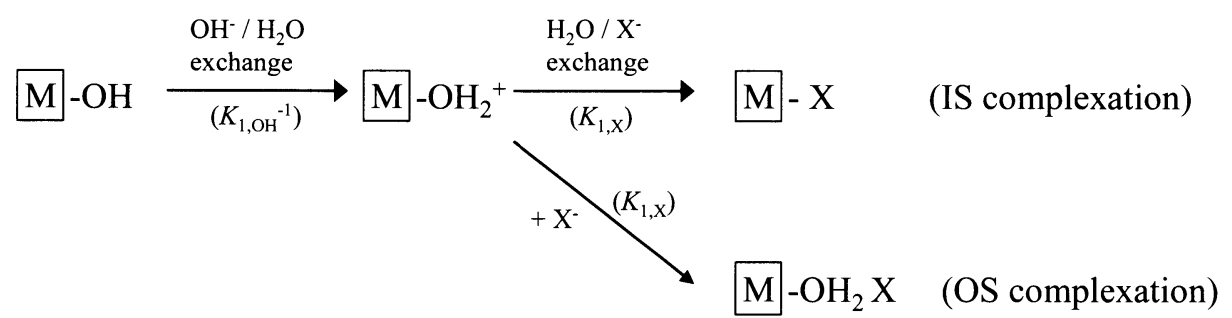

where $K_{1, \mathrm{OH}}$ and $K_{1, \mathrm{X}}$ are the stability constants given as follows. A random mixing of anions on $\mathrm{HMeO}$ is assumed and the electrostatic term is ignored since high ionic strength is assumed.

$$
\begin{array}{lll}
\mathrm{M}^{n+}{ }_{\text {aq. }}+\mathrm{OH}^{-} \rightleftarrows \mathrm{M}(\mathrm{OH})^{(n-1)+} & & K_{1, \mathrm{OH}}=[\mathrm{M}(\mathrm{OH})] /([\mathrm{M}][\mathrm{OH}]) \\
& & \text { (stability constant for OH coordination) } \\
\mathrm{M}^{n+}{ }_{\text {aq. }}+\mathrm{X}^{-} \rightleftarrows \mathrm{MX}^{(n-1)+} & K_{1, \mathrm{X}}=[\mathrm{MX}] /([\mathrm{M}][\mathrm{X}])
\end{array}
$$

(stability constant for $\mathrm{X}$ coordination)

The selectivity of anion exchange can be evaluated from the value of $K_{1, \mathrm{X}}$, since the stability constant $\left(K_{1, \mathrm{OH}}\right)$ of $\mathrm{H}_{2} \mathrm{O}$ coordination is constant. We cannot distinguish the complexation state (IS or OS state) directly from the stability constant, since it can be calculated from the concentrations of metal-ligand complex, metal ions, and ligand irrespective of the state of metal-ligand complex.

\subsection{The $\mathrm{pH}$ dependence of anion exchange}

The $\mathrm{pH}$ dependence of anion exchange can be calculated using the $K_{1, \mathrm{X}}$ and $K_{1, \mathrm{OH}}$ values. The rate $\left(R_{\mathrm{X}}\right)$ of ion exchange are given as follows,

$$
\begin{aligned}
R_{\mathrm{X}}= & {[\mathrm{MX}] /([\mathrm{MX}]+[\mathrm{M}(\mathrm{OH})]) } \\
& =K_{1, \mathrm{X}}[\mathrm{X}] /\left(K_{1, \mathrm{OH}}[\mathrm{OH}]+K_{1, \mathrm{X}}[\mathrm{X}]\right)=K_{1, \mathrm{X}}[\mathrm{X}] /\left(K_{1, \mathrm{OH}} K_{\mathrm{W}} /[\mathrm{H}]+K_{1, \mathrm{X}}[\mathrm{X}]\right)
\end{aligned}
$$

where $K_{\mathrm{w}}$ is dissociation constant of $\mathrm{H}_{2} \mathrm{O}$. The $\mathrm{pH}$ dependence of anion exchange can be calculated when $K_{1, \mathrm{X}}$ and $K_{1, \mathrm{OH}}$ are available.

The conditions that the OS surface complexation reaction takes place can be calculated using the $K_{1, \mathrm{OH}}$. Since the OS surface complex forms when $\mathrm{M}-\mathrm{X}$ interaction is markedly weaker than the $\mathrm{M}-\mathrm{OH}_{2}$ interaction, the reaction is controlled mainly by the reaction of $\mathrm{H}_{2} \mathrm{O}$ coordination on central metal. The rate $\left(R_{\mathrm{aq}}\right)$ of aqua-complex is given as,

$$
R_{\mathrm{aq}}=[\mathrm{M}] /([\mathrm{M}]+[\mathrm{M}(\mathrm{OH})])=\left(K_{1, \mathrm{OH}} K_{\mathrm{W}}[\mathrm{H}]^{-1}+1\right)^{-1}
$$

Equation 7 shows that the conditions that OS complex forms depends only on $\mathrm{pH}$, but not on anion concentration.

\section{Results and Discussion}

\subsection{Selectivity sequence}


The first stepwise stability constants $\left(K_{1, \mathrm{X}}\right)$ of diand tri-valent metal ions for halide and oxo anions are summarized in Figure 2. They are obtained by averaging the $K_{1, \mathrm{X}}$ values at ionic strength between 0.5 and 2 , since the influence of electrostatic interaction decreases at high salt concentration due to the shielding effect of electric field by added salt (ions). The $K_{1, \mathrm{X}}$ value varies depending on central metal ions similar to the experimental results in Table 1. The selectivity sequences for $\mathrm{HMeO}$ can be predicted from these $K_{1, \mathrm{X}}$ values as follows,

[Central metal]

$$
\begin{array}{ll}
\mathrm{Fe}^{3+}: & \mathrm{F}^{-}>\mathrm{SO}_{4}{ }^{2-}>\mathrm{Cl}^{-}>\mathrm{BrO}_{3}{ }^{-}>\mathrm{NO}_{3}{ }^{-}>\mathrm{Br}^{-}>\mathrm{ClO}_{3}{ }^{-} \\
\mathrm{Bi}^{3+}: & \mathrm{F}^{-}>\mathrm{I}^{-}>\mathrm{Cl}^{-}>\mathrm{Br}^{-}>\mathrm{SO}_{4}{ }^{2-}>\mathrm{NO}_{3}{ }^{-} \\
\mathrm{Zn}^{2+}: & \mathrm{F}^{-}, \mathrm{SO}_{4}{ }^{2-}>\mathrm{Cl}^{-}>\mathrm{ClO}_{3}^{-}, \mathrm{NO}_{3}{ }^{-}>\mathrm{Br}^{-}>\mathrm{I}^{-} \\
\mathrm{Pb}^{2+}: & \mathrm{F}^{-}>\mathrm{I}^{-}>\mathrm{SO}_{4}{ }^{2-}, \mathrm{Br}^{-}>\mathrm{Cl}^{-}>\mathrm{NO}_{3}{ }^{-}>\mathrm{ClO}_{3}^{-}
\end{array}
$$

The selectivity sequences agree comparatively well with those in Table 1. Similar to the experimental results, the HSAB relationship is observed; the HMeOs with hard acid metals $\left(\mathrm{Fe}^{3+}, \mathrm{Zn}^{2+}\right)$ shows high selectivity for $\mathrm{F}^{-}$, while those with borderline acid $\left(\mathrm{Bi}^{3+}, \mathrm{Pb}^{2+}\right)$ relatively high selectivity for I. Although experimental results are not available, the selectivity sequences of hydrous magnesium oxide and hydrous cadmium oxide can be predicted as follows,

[Central metal]

$$
\begin{array}{ll}
\mathrm{Mg}^{2+}: & \mathrm{F}^{-}>\mathrm{SO}_{4}{ }^{2-}>\mathrm{Cl}^{-}>\mathrm{Br}^{-} \\
\mathrm{Cd}^{2+}: & \mathrm{I}^{-}>\mathrm{Br}^{-}>\mathrm{Cl}^{-}>\mathrm{F}^{-}>\mathrm{SO}_{4}{ }^{2-}>\mathrm{IO}_{3}{ }^{-}>\mathrm{NO}_{3}{ }^{-}>\mathrm{ClO}_{3}{ }^{-}
\end{array}
$$

Since $\mathrm{Cd}^{2+}$ belongs to soft acid, the predicted selectivity sequence for halide ions agrees with the Hofmeister series. The $K_{1, \mathrm{X}}$ values of tetraalkyl ammonium ions for anions are given in the bottom of Figure 2 as a model functional group of strong base anion exchange resin. The selectivity sequence $\left(\mathrm{I}^{-}>\mathrm{Br}^{-}>\mathrm{Cl}^{-}\right)$for halide ions follows the normal Hofmeister series, suggesting that these anions interact with the functional group in a hydrated state. This also follows the HSAB rule.

\section{$4.2 \mathrm{pH}$ dependence of anion exchange}

The $\mathrm{pH}$ dependence of anion exchange can be evaluated using eq. 6 when ligand concentration and $K_{1, \mathrm{OH}}$ are known in addition to the $K_{1, \mathrm{X}}$ values. The calculated $\mathrm{pH}$ dependences of $\mathrm{Cl}^{-}$and $\mathrm{F}^{-}$exchanges and the experimental result [15] for $\mathrm{Cl}^{-}$exchange are shown in Figure 3 at a solute concentration of $0.1 \mathrm{M}$. Since the
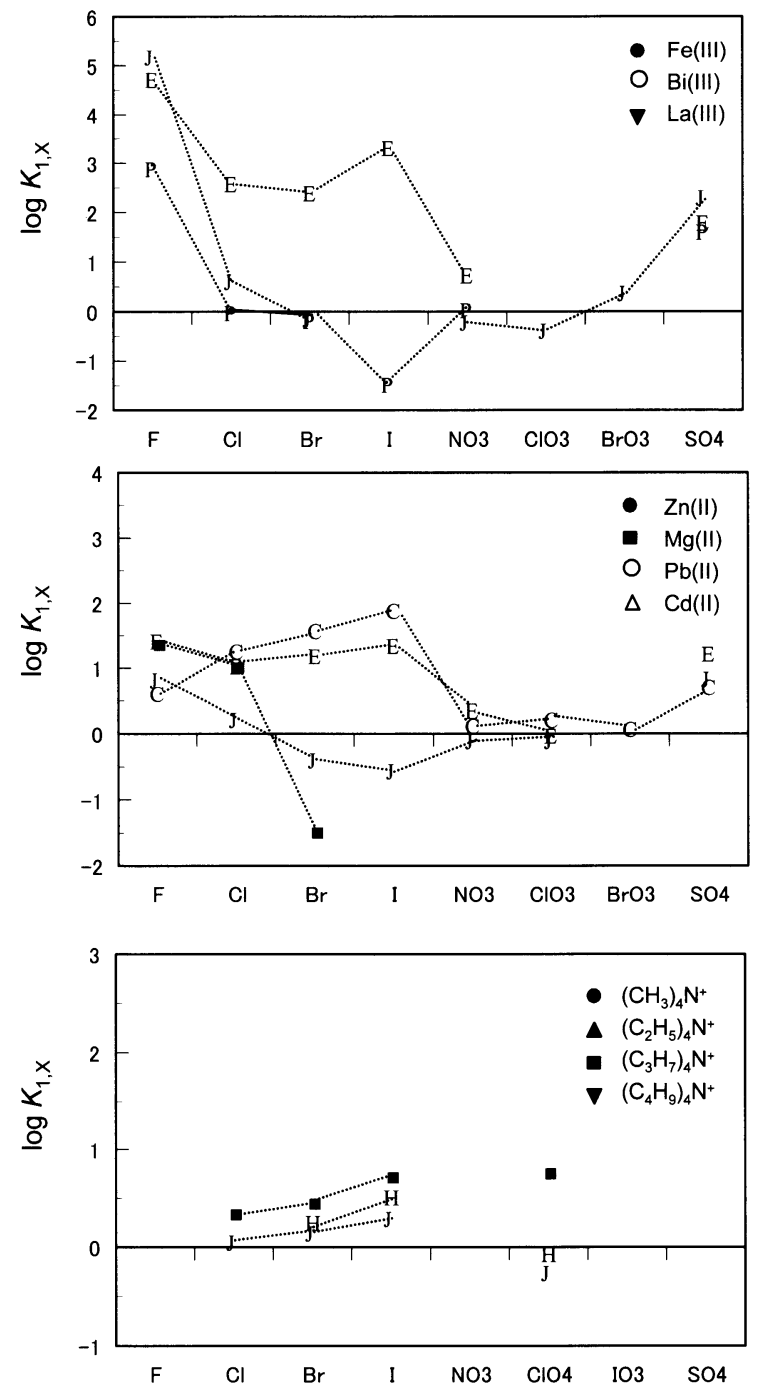

Figure 2 First stepwise stability constant of metal ions for various anions.

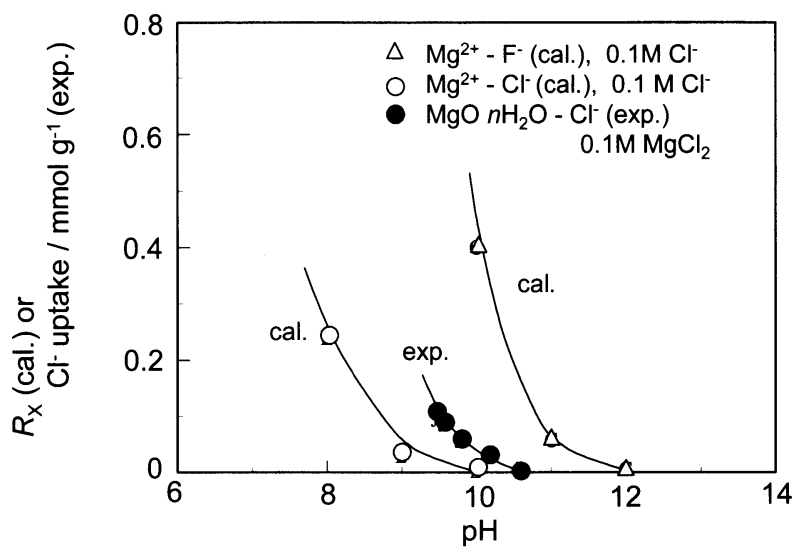

Figure 3 The calculated and experimental $\mathrm{pH}$ dependences of anion exchange. $\log K_{1, \mathrm{OH}}=7.3$. 
exchange capacity of $\mathrm{MgO} \mathrm{nH} \mathrm{H}_{2} \mathrm{O}$ is not available, the $R_{\mathrm{X}}$ value cannot be calculated from the experimental uptake curve. Therefore, the $\mathrm{pH}$ values that start anion exchange is meaningful at present. The starting $\mathrm{pH}$ value agrees well between the calculated and experimental results for $\mathrm{Cl}^{-}$exchange on hydrous magnesium oxide.

The conditions that form IS or OS surface complex can be calculated using eqs. 6 and 7. The $\mathrm{pH}$ dependences of $\mathrm{Cl}^{-}$and $\mathrm{H}_{2} \mathrm{O}$ exchanges with hydoxylated $\mathrm{Fe}^{3+}$ are given in Figure 4. The $\mathrm{Cl}^{-}$exchange depend on solute

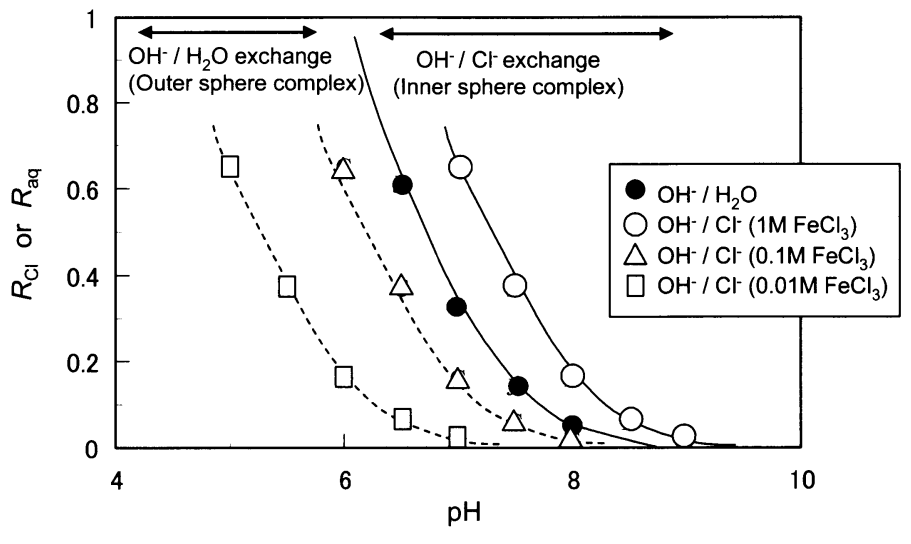

Figure 4 The $\mathrm{pH}$ dependences of $\mathrm{Cl}^{-} / \mathrm{OH}^{-}$and $\mathrm{Cl}^{-} / \mathrm{H}_{2} \mathrm{O}$ exchanges with $\mathrm{Fe}^{3+}$ system. concentration according to eq.6; the exchange curve shift to lower $\mathrm{pH}$ region with the decrease of solute concentration. While the $\mathrm{H}_{2} \mathrm{O}$ exchange does not depend on solute concentration according to eq. 7. Fig. 4 shows that the IS surface complex forms at $1 \mathrm{M} \mathrm{FeCl}_{3}$ while the $\mathrm{OH}^{-} / \mathrm{H}_{2} \mathrm{O}$ exchange is predominant and the OS surface complex forms in the region of $\mathrm{FeCl}_{3}$ concentration below $0.1 \mathrm{M}$, This shows that the structure of surface complex varies depending on solute concentration. The conditions whether IS or OS complex forms can be written as follows,

$$
\begin{array}{ll}
K_{1, \mathrm{X}}[\mathrm{X}]>1 & \text { (formation of IS surface complex) } \\
K_{1, \mathrm{X}}[\mathrm{X}]<1 & \text { (formation of OS surface complex) }
\end{array}
$$

In the system with lower $K_{1, \mathrm{X}}$, for examples $\mathrm{Mg}^{2+}-\mathrm{Br}^{-}, \mathrm{Zn}^{2+}-\mathrm{Br}^{-}$, and $\mathrm{Fe}^{3+}-\mathrm{ClO}_{3}{ }^{-}$systems, the $\mathrm{OS}$ surface complex tends to form at low solute concentrations.

\section{References}

1) M. Abe, "Inorganic Ion Exchange Materials" (Ed. A. Clearfield), CRC Press Inc., Florida (1982), Chap. 6, pp. 161-273.

2) K. F. Hayes, G. Redden, W. Ela, and J. O. Leckie. J. Colloid Interface Sci., 142, 448 - 469 (1991).

3) D. A. Sverjensky and K. Fukushi, Geochim. Cosmochim. Acta, 70, 3778 - 3802 (2006).

4) W. Szczepaniak and H. Koscielna, Anal. Chim. Acta, 470, 263 - 276 (2002).

5) The IUPAC stability constant data base. Ver. 5.81.

6) W. Stumm, Colloids Surfaces A, 73, 1 - 18 (1993).

7) M. Abe, "Ion Exchange and Solvent Extraction Vol. 12" (Eds. J. A. Marinsky and Y. Marcus), Marcel Dekker, Inc., New York (1995). Chap. 9, pp.381-440.

8) R. Chitrakar, S. Tezuka, A. Sonoda, K. Sakane, K. Ooi, and T. Hirotsu, J. Colloid Interface Sci., 298, 602 608 (2006).

9) M. Seno, M. Abe, and T. Suzuki, eds., "Ion Koukan", Kodansha, Tokyo (1991). pp. 269. (in Japanese)

10) A. Dyer and S. A. Malik, J. inorg. nucl. Chem., 43, 2975 - 2978 (1981).

11) M. Tsuji and M. Abe, J. Radioanal. Nucl. Chem., 149, 109 - 118 (1991).

12) H. Imai, J. Nomura, Y. Ishibashi, and T. Konishi, Nippon Kagaku Kaishi, 1987, 807 - 813. (in Japanese)

13) Y. Inoue, Y. Suzuki, and T. M. Suzuki, Bunseki Kagaku, 42, T155 - T160 (1993). (in Japanese)

14) R. G. Pearson, J. Chem. Educ., 45, 581 -587 (1968).

15) M. Abe and T. Ito, Nippon Kagaku Zasshi, 86, 817 - 823 (1965). (in Japanese). 